\title{
Beyond Gap Junction Channel Function: the Expression of Cx43 Contributes to Aldosterone-Induced Mesangial Cell Proliferation via the ERK1/2 and PKC Pathways
}

\author{
Aiqing Zhang ${ }^{\mathrm{a}}$ Ying Han ${ }^{\mathrm{b}}$ Bin Wang ${ }^{\mathrm{c}}$ Shanwen Lia Weihua Gan
}

aDepartment of Pediatric Nephrology, the Second Affiliated Hospital of Nanjing Medical University, Nanjing, 'Department of Paediatrics, Zibo Maternity and Child Health Hospital, Zibo, 'Division of Nephrology, Huashan Hospital and Institute of Nephrology, Fudan University, Shanghai, P. R. China

\section{Key Words}

Connexin 43 - Gap junction • Mesangial cells • Proliferation

\begin{abstract}
Aims: This study aimed to explore the precise mechanism and signaling pathways of mesangial cell (MC) proliferation from a new point of view considering Connexin 43 (Cx43). Methods: MC proliferation was measured by the incorporation of $3 \mathrm{H}$-thymidine (3H-TdR). Cx43 was over-expressed in MC cells using lipofectamine 2000, and the expression level was tested with reverse transcription-polymerase chain reaction (RT-PCR) and Western blot analyses. The gap junction channel function was explored by Lucifer Yellow scrape loading and dye transfer (SLDT), and the intracellular calcium concentrations $\left(\left[\mathrm{Ca}^{2+}\right]_{\mathrm{i}}\right)$ were characterized by confocal microscopy on cells loaded with Fura-3/AM. Results: There was an inverse correlation between Cx43 expression and MC proliferation $(P<0.05)$. SLDT studies revealed that there was no difference in the gap junction channel function between the normal and Aldosterone (Aldo)stimulated groups $(P>0.05)$. Our data also showed that the mineralcorticoid receptor (MR) antagonist spironolactone, ERK1/2 inhibitor PD98059 and PKC inhibitor GF109203X could attenuate the down-regulation of $\mathrm{C} \times 43$ expression in Aldo-induced $\mathrm{MC}$ proliferation; however, the PI3K inhibitor LY294002 could block MC proliferation without affecting Cx43 expression at either the mRNA or protein level. In addition, Aldo promoted $\mathrm{MC}$ proliferation in parallel with increasing $\left[\mathrm{Ca}^{2+}\right]_{i}(\mathrm{P}<0.05)$, suggesting that the classical PKC pathway might be activated. Conclusions: Our study provides preliminary evidence that $\mathrm{Cx} 43$ is an important regulator of Aldo-promoted MC proliferation. Furthermore, reduced Cx43 expression promoted MC proliferation independent of the gap junction channel function, and this process might be mediated through the ERK1/2- and PKC-dependent pathways.
\end{abstract}

A. Zhang and Y. Han contributed equally to this work.

Weihua Gan

KARGER 125
The Second Affiliated Hospital Of Nanjing Medical University,

Zhongshanbeilu 262, Nanjing,J iangsu, 210003 (China)

Tel. +86-25-8357-5027, E-Mail njaiqing@njmu.edu.cn 


\section{Cellular Physiology Cell Physiol Biochem 2015;36:1210-1222 \begin{tabular}{l|l|l}
\cline { 2 - 2 } DOI: 10.1159/000430291 & C 2015 S. Karger AG, Basel
\end{tabular} \begin{tabular}{l|l} 
and Biochemistry Published online: June 30, 2015 & www.karger.com/cpb
\end{tabular} \\ Zhang et al.: Cx43 Regulates Mesangial Cell Proliferation}

\section{Introduction}

The renin-angiotensin-aldosterone system (RAAS) plays a critical role in the progression and prognosis of chronic kidney disease (CKD), leading to inflammation, fibrosis, proteinuria, hypertension and metabolic syndrome [1-5]. Several studies have revealed that the renal mesangial cell (MC) is a target local of aldosterone (Aldo) action, where Aldo can induce glomerular injury characterized by mesangial matrix expansion and cell overgrowth through mineralcorticoid receptor (MR) activation [6-8], ROS generation, epithelial growth factor receptor (EGFR) phosphorylation, cell cycle-regulatory protein expression, and multiple signaling pathways [8-10]. However, the actual molecular mechanism responsible for Aldo-induced MC proliferation is far from clear.

Considering the presence of connexins within the kidney and their functional role in growth regulation [8, 11-13], analysis of connexins provides a new viewpoint for investigating CKD. Connexins are a multi-gene family of transmembrane proteins with $\sim 20$ isoforms. Structurally, six connexins have two hemichannels and then form a gap junction channel. The channel permits the intercellular passage of small molecules (generally less than $1000 \mathrm{Da}$ ), such as inorganic ions (e.g., $\mathrm{Na}+$ and $\mathrm{K}+$ ), second messengers (e.g., $\mathrm{Ca}^{2+}, \mathrm{IP} 3$, and cAMP), hormones, and other metabolites, enabling the neighboring cells to achieve gap junction intercellular communication (GJIC). Connexins and GJIC play crucial roles in the regulation of embryonic development, maintenance of tissue/organ homeostasis, cellular metabolism, morphogenesis, and growth control [14-16]. Of note, Cx43 is the most abundant connexin, and it is the most closely related to cell growth. The $\mathrm{Cx} 43$ lifecycle begins with gene expression, which is followed by oligomerization into hexameric channels to effect intercellular coupling. Accordingly, $\mathrm{Cx} 43$ has dual functions in cell growth regulation, a wellaccepted role in forming a gap junction channel (termed as channel-dependent mechanisms) and a direct action on growth (termed as channel-independent mechanisms).

The purpose of this study is to explore the molecular mechanism of Aldo-induced MC proliferation targeted at $\mathrm{Cx} 43$ expression and/or its gap junction channel function.

\section{Materials and Methods}

The rat mesangial cell line HBZY-1 was obtained from the Chinese Center for Type Culture Collection (Wuhan, China). Cell culture materials were purchased from Gibco BRL (Gaithersburg, MD, USA). Aldo, Spironolactone (Spi), Lucifer Yellow (LY), GF109203X (PKC inhibitor), and Fura-3/AM were from Sigma Chemical Co. (St. Louis, MO, USA). PD98059 (ERK1/2 inhibitor) and LY294002 (PI3K inhibitor) were purchased from Calbiochem (Cambridge, MA, USA). Antibodies against Cx43, $\beta$-actin and all secondary horseradish peroxidase-conjugated antibodies were obtained from Cell Signaling Technology, Inc. (Beverly, MA, USA). Immobilon PVDF membrane was obtained from Millipore (Bedford, MA, USA). All other chemicals are analytical grade.

\section{Cell culture and transfection}

The rat MCs were cultured in Dulbecco's modified Eagle's medium (DMEM) supplemented with 10\% fetal calf serum (FCS), $2 \mathrm{mM}$ glutamine, $100 \mathrm{U} / \mathrm{ml}$ penicillin, and $100 \mathrm{mg} / \mathrm{ml}$ streptomycin at $37{ }^{\circ} \mathrm{C}$ in an atmosphere containing $5 \% \mathrm{CO}_{2}$ before being used in the different experiments. For passage, confluent cells were first washed with PBS and then removed with $0.25 \%$ trypsin / $0.5 \mathrm{mM}$ EDTA in PBS and plated in DMEM. MCs were used for experiments at passages 3 to 16.

Plasmid transfections were performed with the lipofectamine ${ }^{\mathrm{TM}} 2000$ (lipo 2000) transfection reagent according to the manufacturer's instructions (Invitrogen). Briefly, one day before transfection, $2 \times 10^{5}$ cells were plated in $500 \mu \mathrm{l}$ of growth medium without fetal serum and antibiotics. The rat wild-type cd43 in the pcDNA vector was gently mixed with lipo 2000 at a ratio of 1:2.5. The appropriate amount of complexes was added to a well containing cells and medium, and the medium was replaced after 4-6 h; cells were incubated for $48 \mathrm{~h}$ prior to testing for transgene expression.

\section{KARGER}




\section{Cellular Physiology Cell Physiol Biochem 2015;36:1210-1222 \begin{tabular}{l|l|l}
\hline DOI: 10.1159/000430291 & (C) 2015 S. Karger AG, Basel
\end{tabular} \begin{tabular}{l|l|l|l|l} 
and Biochemistry Published online: June 30, 2015 & www.karger.com/cpb
\end{tabular} \\ Zhang et al.: Cx43 Regulates Mesangial Cell Proliferation}

\section{MC proliferation assay}

The incorporation of $3 \mathrm{H}$-thymidine (3H-TdR) was used to measure MC proliferation. Cells were seeded into 96-well plates $\left(5 \times 10^{3} /\right.$ well $)$ and grown for $24 \mathrm{~h}$ in $10 \%$ FCS-DMEM; they were then preincubated in $0.5 \%$ FCS-DMEM for another $24 \mathrm{~h}$. To assess the concentration effect of Aldo, MCs were stimulated by Aldo in concentrations ranging from $0.1 \mathrm{nM}$ to $100 \mathrm{nM}$ ( $\mathrm{n}=6$ for each) for $24 \mathrm{~h}$. To explore the underlying mechanisms of MC proliferation, the MR antagonist spironolactone (Spi, $10 \mathrm{nM}$ ), ERK1/2 inhibitor PD98059 $(10 \mu \mathrm{M})$, PI3K inhibitor LY294002 $(10 \mu \mathrm{M})$ or PKC inhibitor GF109203X (10 $\mu \mathrm{M})$ was administered with or without $100 \mathrm{nM}$ Aldo for $24 \mathrm{~h}$. As previously described by Huang [6], cells were pulsed with $1 \mu \mathrm{Ci} / \mathrm{mL} 3 \mathrm{H}-\mathrm{TdR}$ during the final $5 \mathrm{~h}$, harvested, and counted on a scintillation counter. The level of 3H-TdR incorporation is represented by $\mathrm{Cpm}$, and the final results are expressed as the percentage of the control group.

\section{Reverse Transcription-Polymerase Chain Reaction (RT-PCR)}

To evaluate the expression level of $\mathrm{Cx} 43$ mRNA, we adopted a semiquantitative RT-PCR technology. Total RNA (1 ug) extracted from MC with TRIZOL (Gibco BRL, Gaithersburg, MD) was reversetranscribed using Superscript reverse transcriptase (Invitrogen) to yield the respective cDNA. The RNA concentrations were determined by measuring the A260 / A280 absorption. The efficiency of RT-PCR was controlled by glyceraldehyde-3-phosphate dehydrogenase (GAPDH) amplification. Each sample mixture contained standard PCR buffer, $2.5 \mathrm{mM}$ dNTP, $2 \mathrm{U}$ Taq polymerase, and $5 \mathrm{pM}$ of each of the following primers: GAPDH, 5'-CAAGTTCAACGGCACAGTCAA-3' and 5'-TGGTGAAGACGCCAGTAGACTC-3', and cx43, 5'-TCTGCCTTTCGCTGTAACACT-3' and 5'-GGGCACAGACACGAATATGAT-3'. The PCR cycles consisted of 30 cycles of a step at $95^{\circ} \mathrm{C}$ for $1 \mathrm{~min}$, a denaturation step at $94^{\circ} \mathrm{C}$ for $30 \mathrm{~s}$, an annealing step at $57.5^{\circ} \mathrm{C}$ and an extension step at $72^{\circ} \mathrm{C}$ for $30 \mathrm{~s}$, followed by a final extension at $72^{\circ} \mathrm{C}$ for $7 \mathrm{~min}$. The expected PCR product sizes were $149 \mathrm{bp}$ (for GAPDH) and $117 \mathrm{bp}$ (for cx43). The products were subjected to computer-assisted densitometry after electrophoresis on a 1.5\% agarose gel and staining with ethidium bromide.

\section{Western blotting}

After the treatment with different compounds for the indicated time, the cells were harvested and washed with ice-cold phosphate buffer. Total cellular proteins were extracted by lysing cells with buffer containing $150 \mathrm{mM} \mathrm{NaCl}, 0.1 \%$ Triton X-100, 0.5\% Deoxycholate, $0.1 \%$ sodium dodecyl sulfate (SDS), $50 \mathrm{mM}$ Tris-HCl (pH 7.0), and $1 \mathrm{mM}$ ethylenediaminetetraacetic acid (EDTA), and nuclear proteins were obtained using previously described methods. The protein concentrations were determined with the BCA method (Beyotime Institute of Biotechnology, China). Thirty micrograms of protein extract was loaded onto each lane, separated by SDS-polyacrylamide gel electrophoresis (PAGE), and transferred to nitrocellulose membranes. After being blocked with $5 \% \mathrm{w} / \mathrm{v}$ bovine serum albumin (BSA), $1 \mathrm{x}$ Tris-buffered saline (TBS) ( $\mathrm{pH} 7.6$ ), and $0.1 \%$ Tween-20 at room temperature, the membranes were incubated at $4{ }^{\circ} \mathrm{C}$ overnight with primary antibodies for total $\mathrm{Cx} 43$ (1:1000) and $\beta$-actin (1:3000). After being incubated with the respective second antibody, immune complexes were detected by ECL Western blotting reagents. The detected proteins were normalized to $\beta$-actin as appropriate.

\section{Measurement of the gap junction channel function}

The gap junction channel function was detected by SLDT. In brief, confluent MCs in $35 \mathrm{~mm}$ dishes were starved for $24 \mathrm{~h}$ in $0.5 \%$ FCS-DMEM. To detect the dose-dependent GJIC function of Aldo, MCs were incubated with Aldo at a concentration of $0.1,1,10$ or $100 \mathrm{nM}$ for $24 \mathrm{~h}$. After Aldo treatment, the cells were rinsed three times with phosphate-buffered saline (PBS), and $1 \mathrm{ml}$ of $0.05 \%$ Lucifer Yellow $(0.05 \% \mathrm{~V} / \mathrm{V}$ dissolved in PBS) was then added to the cell cultures and scrape loaded with several scrapes using a steel surgical blade. The dye solution was left on the cell cultures for $3 \mathrm{~min}$ and then discarded. The cell cultures were carefully rinsed three times with PBS to remove detached cells and background fluorescence. An inverted fluorescence microscope (Olympus, Japan) was employed to record the migration of the Lucifer Yellow dye from the edge cells of the scrape. An average value of 9 measurements for each treatment ( 3 measurements per dish) was regarded as the migration of dye in the cell cultures. The percentage of migration of dye in the cell cultures exposed to target compounds to the migration of dye traveling in the vehicle control was recorded to evaluate the function of GJIC. 


\section{Cellular Physiology Cell Physiol Biochem 2015;36:1210-1222 \begin{tabular}{l|l|l|} 
DOI: 10.1159/000430291 & O 2015 S. Karger AG, Basel
\end{tabular} www.karger.com/cpb \\ Zhang et al.: Cx43 Regulates Mesangial Cell Proliferation}

Measurement of the Intracellular calcium concentrations $\left(\left[\mathrm{Ca}^{2+}\right]_{i}\right)$

The intracellular calcium concentrations $\left(\left[\mathrm{Ca}^{2+}\right]_{i}\right)$ were examined with laser scanning confocal microscopy after being loaded with Fura-3/AM. Cells were seeded into 6 -well plates $\left(4 \times 10^{5} /\right.$ well $)$ with a glass bottom after being treated with Aldo at a concentration of $0.1,1,10$ or $100 \mathrm{nM}$ for $24 \mathrm{~h}$. Cells were harvested and washed with PBS three times, treated with $5 \mu \mathrm{M}$ Fura-3/AM (dissolved in DMSO) and then incubated at $37{ }^{\circ} \mathrm{C}$ for $30 \mathrm{~min}$. Afterwards, cells were washed with PBS another three times to remove the unloaded Fura-3/AM, and they were immediately observed using laser scanning confocal microscopy (LSM710, Germany) with an excitation wavelength of $488 \mathrm{~nm}$ and emission wavelength of $525 \mathrm{~nm}$. The gray value of the fluorescence represents the $\left[\mathrm{Ca}^{2+}\right]_{i}$, which was directly obtained from the computer connected to the LSM analysis system. The final results are presented as the fluorescence gray value.

\section{Statistical analysis}

SPSS17.0 statistical software was used for the statistical analysis. All values are expressed as the mean \pm S.D. The differences were tested using analysis of variance (ANOVA). A P-value of less than 0.05 was considered statistically significant.

\section{Results}

Effects of Aldo on MC Proliferation and DNA synthesis rate

The incorporation of 3H-TdR showed that Aldo increased MC proliferation in a dosedependent manner, ranging from $0.1 \mathrm{nM}$ to $100 \mathrm{nM}(\mathrm{P}<0.05, \mathrm{n}=6)$ (Fig.1.A). Additionally, 100 $\mathrm{nM}$ Aldo achieved its desired effect of promoting MC proliferation. Next, the MR antagonist spironolactone (Spi, $10 \mathrm{nM}$ ), ERK1/2 inhibitor PD98059 (10 $\mu \mathrm{M}$ ), PI3K inhibitor LY294002 $(10 \mu \mathrm{M})$ or PKC inhibitor GF109203X $(10 \mu \mathrm{M})$ was administered concomitantly with 100 $\mathrm{nM}$ Aldo for $24 \mathrm{~h}$. The data showed that MC proliferation was inhibited to various degrees $(\mathrm{P}<0.01, \mathrm{n}=6)$ (Fig.1.B). However, exposing MCs to an individual inhibitor alone for $24 \mathrm{~h}$ did not affect $\mathrm{MC}$ growth compared to the control group ( $\mathrm{P}>0.05, \mathrm{n}=6)$ (Fig.1.B).

Fig. 1. A) Effects of Aldo on MC proliferation by $3 \mathrm{H}$-thymidine (3H-TdR) incorporation. B). Involvement of MR, ERK1/2, PI3K and PKC in Aldo-induced MC proliferation. Spironolactone (10 nM), PD98059 (10 $\mu \mathrm{M})$, LY294002 $(10 \mu \mathrm{M})$ or GF109203X $(10 \mu \mathrm{M})$ was administered with or without $100 \mathrm{nM}$ Aldo for $24 \mathrm{~h}$ in cultured MC. "Control" refers to cells growing in DMEM containing $10 \% \mathrm{FCS}$ without Aldo intervention. Values are given as the mean $\pm S$.D, and $p<0.05$ is considered statistically significant by ANOVA ( $\mathrm{n}=6,{ }^{*} \mathrm{p}<0.05,{ }^{* *} \mathrm{p}<0.01$ vs. control, $\# \mathrm{p}<0.05, \# \# \mathrm{p}<0.01$ vs. $100 \mathrm{nM}$ Aldo group).

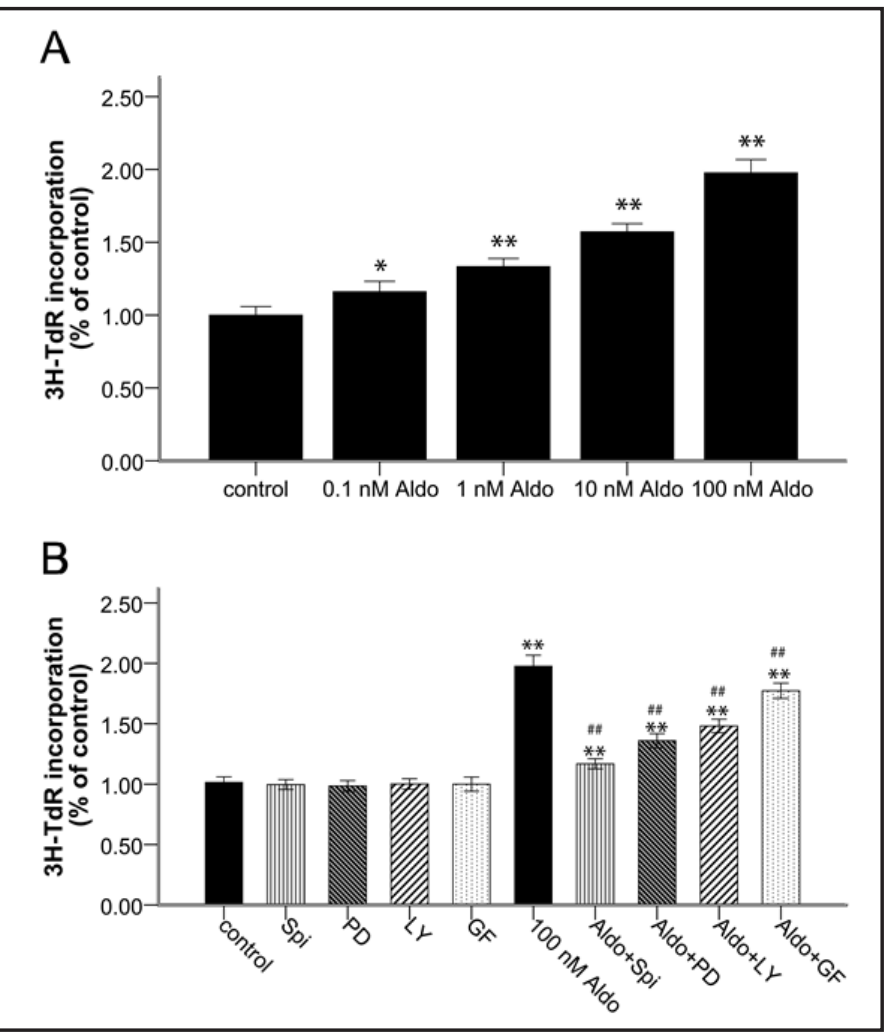




\section{Cellular Physiology}

and Biochemistry
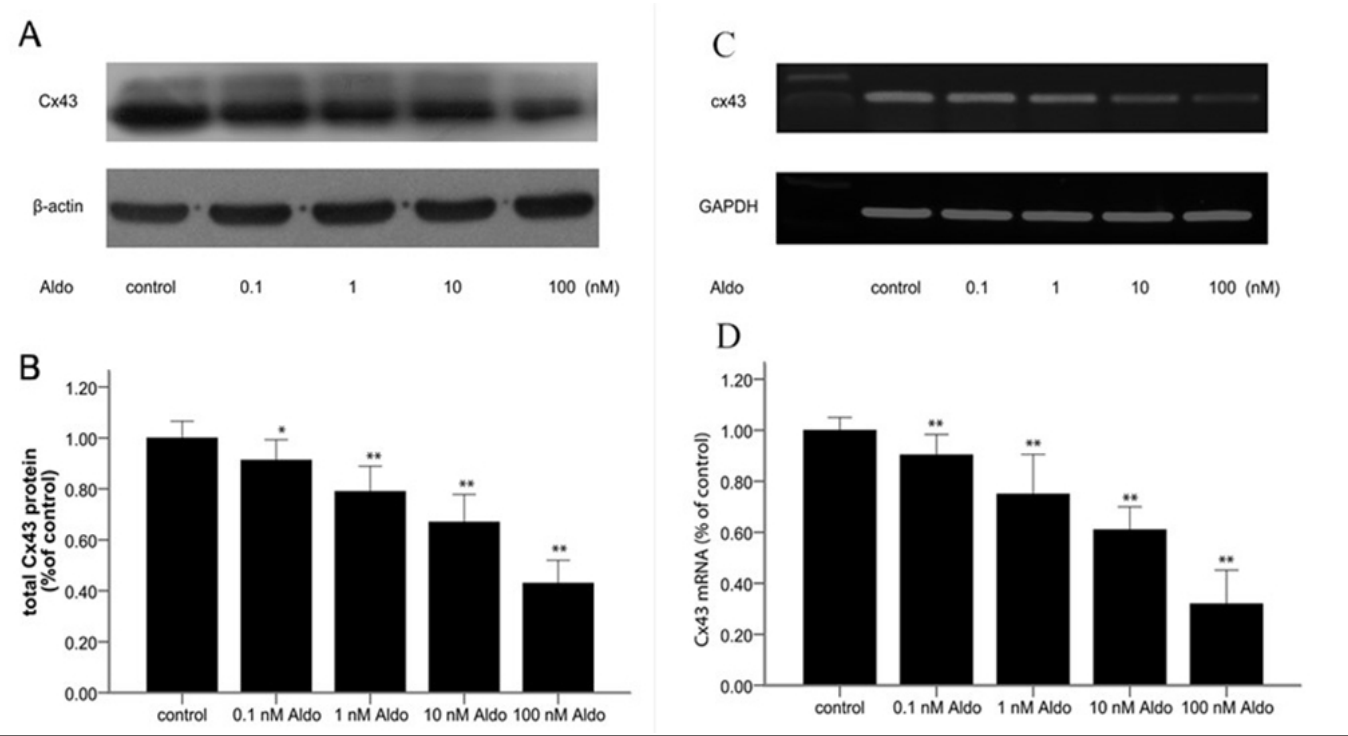

Fig. 2. A and B) Effects of Aldo on the protein expression of $\mathrm{Cx} 43$ by Western blot analysis. The rat MCs were treated with Aldo at a concentration of $0.1,1,10$ or $100 \mathrm{nM}$ for $24 \mathrm{~h}$. Total cellular protein was extracted. Thirty micrograms of protein was loaded for Western blot analysis of total Cx 43 and $\beta$-actin. C and D) Effects of Aldo on Cx43 mRNA by RT-PCR. The rat MCs were treated with Aldo at a concentration of $0.1,1,10$ or $100 \mathrm{nM}$ for $24 \mathrm{~h}$. Total RNA was extracted from cultured MCs and analyzed by RT-PCR as described in the Materials and Methods for Cx43 and GAPDH. "Control" refers to cells growing in DMEM containing 10\% FCS without Aldo intervention. Values are given as the mean \pm S.D, and $p<0.05$ is considered statistically significant by ANOVA ( $n=3,{ }^{*} \mathrm{p}<0.05,{ }^{* *} \mathrm{p}<0.01$ vs. control).

\section{Effects of Aldo on the Expression of Cx43}

Cultured MCs were stimulated for $24 \mathrm{~h}$ with Aldo in increasing concentrations of 0.1, $1,10 \mathrm{nM}$ and $100 \mathrm{nM}$, and Aldo significantly decreased the level of total Cx43 in a dosedependent manner as follows: $0.1 \mathrm{nM}$ Aldo: $0.91 \pm 0.02(\mathrm{P}<0.05, \mathrm{n}=3$ ), $1 \mathrm{nM}$ Aldo: $0.79 \pm 0.02$ $(\mathrm{P}<0.01, \mathrm{n}=3), 10 \mathrm{nM}$ Aldo: $0.67 \pm 0.03(\mathrm{P}<0.01, \mathrm{n}=3)$, and $100 \mathrm{nM}$ Aldo: $0.43 \pm 0.02(\mathrm{P}<0.01$, $\mathrm{n}=3$ ), compared to $\beta$-actin expression, which did not change with the treatment (Fig. 2.A and B).

To determine whether this down-regulation of the protein level of Cx43 expression is due to regulation of transcription rather than due to $\mathrm{Cx} 43$ protein degradation or some other mechanism, semi-quantitative RT-PCR studies were performed. Cx43 mRNA relative to the housekeeping gene GAPDH reduced gradually with concentrations as follows: $0.1 \mathrm{nM}$ Aldo: $0.90 \pm 0.02(\mathrm{P}<0.01, \mathrm{n}=3), 1 \mathrm{nM}$ Aldo: $0.75 \pm 0.04(\mathrm{P}<0.01, \mathrm{n}=3), 10 \mathrm{nM}$ Aldo: $0.61 \pm 0.02$ $(\mathrm{P}<0.01, \mathrm{n}=3)$, and $100 \mathrm{nM}$ Aldo: $0.32 \pm 0.03(\mathrm{P}<0.01, \mathrm{n}=3)$ (Fig. 2.C and D).

\section{Effects of Aldo on MC Proliferation with elevated Cx43 expression}

The data presented in Fig. 3 indicate that the rat wild-type Cx43 vector increased the expression of the total $\mathrm{Cx} 43$ protein $(\mathrm{P}<0.01, \mathrm{n}=3)$. To further assess the role of $\mathrm{Cx} 43$ in Aldo-induced MC proliferation, cell proliferation was analyzed following treatment with different concentrations of Aldosterone in the presence or absence of $\mathrm{Cx} 43$ over-expression for $24 \mathrm{~h}$. Under elevating Cx43 protein expression level by plasmid transfection, Aldoinduced MC proliferation was decreased as follows (Fig.4): control group: 1.00 $\pm 0.56 ; 0.1$ nM Aldo: $1.16 \pm 0.69,0.1 \mathrm{nM}$ Aldo + Cx43 over-expression: $0.85 \pm 0.06(\mathrm{P}<0.01, \mathrm{n}=6) ; 1 \mathrm{nM}$ Aldo: $1.33 \pm 0.53,1 \mathrm{nM}$ Aldo $+\mathrm{Cx} 43$ over-expression: $0.98 \pm 0.07(\mathrm{P}<0.01, \mathrm{n}=6)$; $10 \mathrm{nM}$ Aldo: $1.57 \pm 0.53,10 \mathrm{nM}$ Aldo + Cx43 over-expression: $1.47 \pm 0.09(\mathrm{P}<0.01, \mathrm{n}=6)$; and $100 \mathrm{nM}$ Aldo: $1.98 \pm 0.87(\mathrm{P}<0.01, \mathrm{n}=6), 100 \mathrm{nM}$ Aldo $+\mathrm{Cx} 43$ over-expression: $1.92 \pm 0.12(\mathrm{P}>0.05, \mathrm{n}=6)$. From two aspects of positive and negative, the data obtained Fig. 2 and Fig. 4 suggested that 
Fig. 3. A) Confirmation of the $\mathrm{Cx} 43$ protein expression level after plasmid transfection by Western blot analysis. The rat MCs were transfected with the Cx43 plasmid, and then total cellular protein was extracted. Thirty micrograms of protein was loaded for Western blot analysis of total $\mathrm{Cx} 43$ and $\beta$-actin. B) Quantitative analysis of the mRNA expression level of Cx43. "Control" refers to cells growing in DMEM containing 10\% FCS without Aldo intervention. The values are given as the mean \pm S.D, and $\mathrm{p}<0.05$ is considered statistically significant by ANOVA $(n=3$, ${ }^{*} \mathrm{p}<0.05,{ }^{* *} \mathrm{p}<0.01$ vs. control).

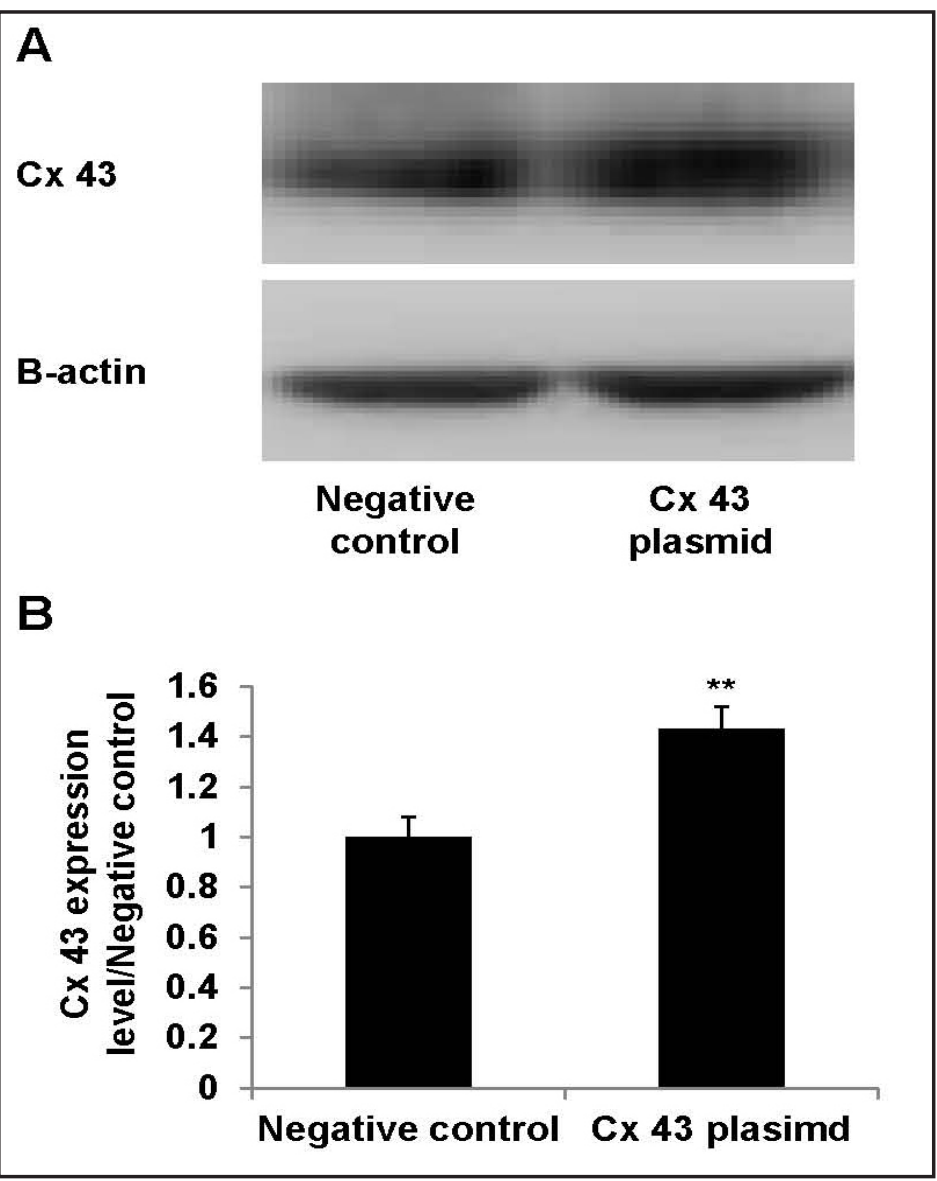

Cx43 expression as a 'negative' regulator contributed to aldosterone-induced mesangial cell proliferation.

Effects of Aldo on the gap junction channel function

To further explore how Cx43 affects MC proliferation, we next performed SLDT. As shown in Fig. 5, none of concentrations of Aldo, ranging from $0.1 \mathrm{nM}$ to $100 \mathrm{nM}$, had any notable effect on GJIC marked by the diffusion length of Lucifer Yellow dye at the following levels ( $\mathrm{p}>0.05, \mathrm{n}=9$ ): control, 100.11 $\pm 2.95 \% ; 0.1 \mathrm{nM}$ Aldo, 97.89 $\pm 2.20 \%$; $1 \mathrm{nM}$ Aldo, 98.11 $\pm 4.17 \%$; $10 \mathrm{nM}$ Aldo, 96.56 $\pm 4.56 \%$; and $100 \mathrm{nM}$ Aldo, 98.00 $\pm 4.47 \%$ ( $>0.05, \mathrm{n}=9$ ), indicating that $\mathrm{Cx} 43$ might contribute to one of the critical mechanisms for MC proliferation that is independent of gap junction channel function

Involvement of $M R, E R K 1 / 2, P I 3 K$ and PKC kinase in CX43 expression in Aldosteroneinduced MC Proliferation

The MR antagonist spironolactone, ERK1/2 inhibitor PD98059 and PKC inhibitor GF109203X (instead of the PI3K inhibitor LY294002) could markedly reverse the downregulation of the $\mathrm{Cx} 43$ expression at the gene level as follows (Fig. 6): Spi $0.92 \pm 0.02$ ( $P>0.05$ vs. control, $\mathrm{p}<0.01$ vs. $100 \mathrm{nM}$ Aldo, $\mathrm{n}=3$ ), $\mathrm{PD} 0.78 \pm 0.03$ ( $\mathrm{P}<0.01$ vs. control, $\mathrm{p}<0.01$ vs. 100 nM Aldo, $\mathrm{n}=3$ ), LY $0.28 \pm 0.03$ ( $\mathrm{P}<0.01$ vs. control, $\mathrm{p}>0.05$ vs. $100 \mathrm{nM}$ Aldo, $\mathrm{n}=3$ ), GF $0.67 \pm 0.04$ $(\mathrm{P}<0.01$ vs. control, $\mathrm{p}<0.01$ vs. $100 \mathrm{nM}$ Aldo, $\mathrm{n}=3)$, which is in parallel with the protein levels as follows (Fig. 7): Spi $0.88 \pm 0.03$ ( $\mathrm{P}<0.05$ vs. control, $\mathrm{p}<0.01$ vs. $100 \mathrm{nM}$ Aldo, $\mathrm{n}=3$ ), PD $0.69 \pm 0.05(\mathrm{P}<0.01$ vs. control, $\mathrm{p}<0.01$ vs. $100 \mathrm{nM}$ Aldo, $\mathrm{n}=3)$, LY $0.33 \pm 0.04(\mathrm{P}<0.01$ vs. control, $\mathrm{p}>0.05$ vs. $100 \mathrm{nM}$ Aldo, $\mathrm{n}=3$ ), and GF $0.54 \pm 0.03$ ( $\mathrm{P}<0.01$ vs. control, $\mathrm{p}<0.01$ vs. $100 \mathrm{nM}$ Aldo, n=3). Similarly, the inhibitor itself did not exert a substantial effect on Cx43 expression compared to the control group $(p>0.05, n=3)$. 
Fig. 4. Effects of Aldo on MC proliferation under elevated Cx43 protein. The rat MCs were treated with Aldo at a concentration of $0.1,1,10$ or $100 \mathrm{nM}$ in the presence or absence of $\mathrm{Cx} 43$ over-expression for $24 \mathrm{~h}$. "Control" refers to cells growing in DMEM containing 10\% FCS without Aldo intervention. The values are given as the mean \pm S.D, and $\mathrm{p}<0.05$ is considered statistically significant by ANOVA $(n=6)$.
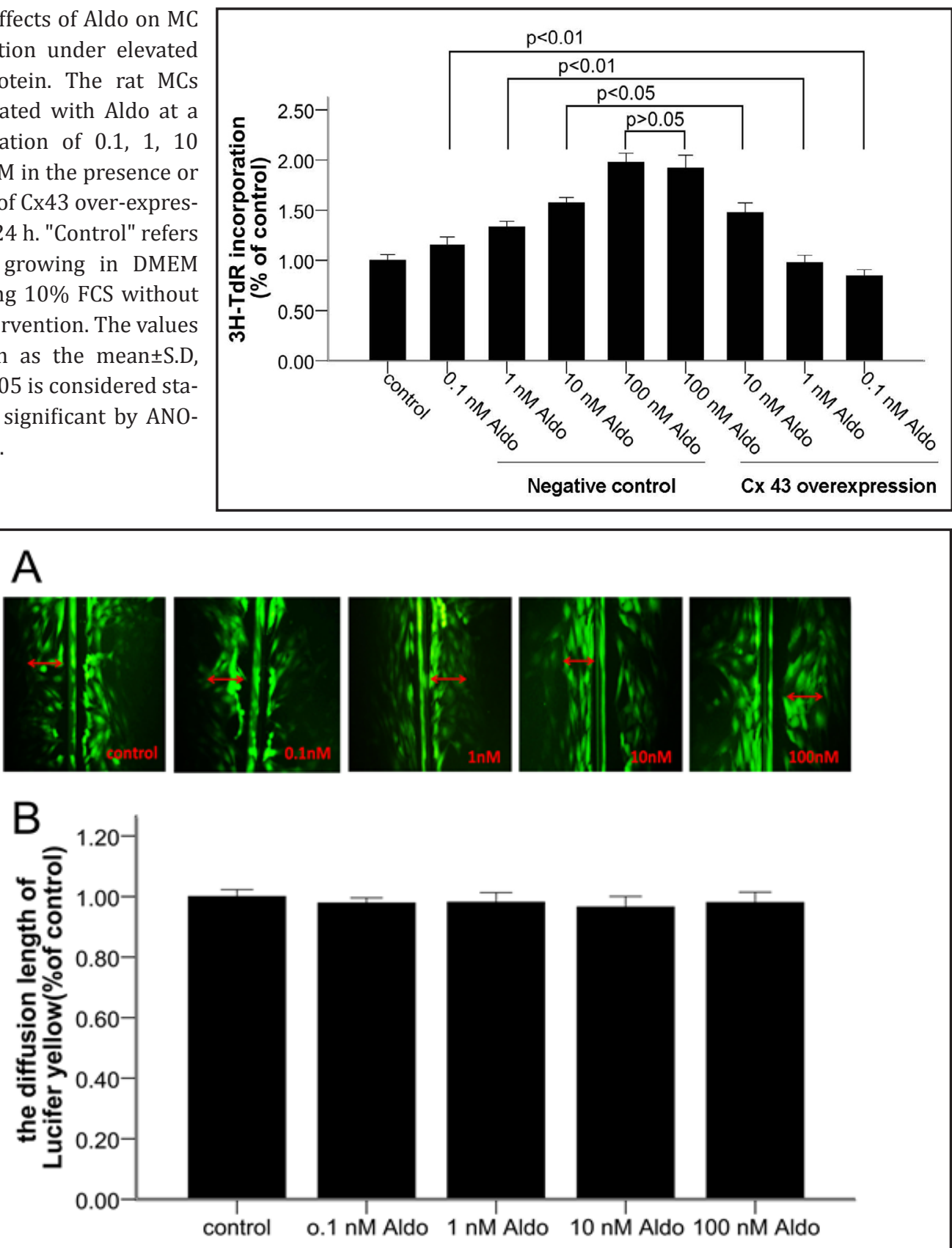

Fig. 5. A) Effects of Aldo on the gap junction channel function using SLDT. Magnification, $\mathrm{x} 100$. The rat MCs were treated with Aldo at a concentration of $0.1,1,10$ or $100 \mathrm{nM}$ for $24 \mathrm{~h}$. Then, SLDT was performed as described in the Materials and Methods. B). Quantitative analysis of the function of GJIC in Aldo-induced MC proliferation. "Control" refers to cells growing in DMEM containing 10\% FCS without Aldo intervention. Values are given as the mean \pm S.D, and $\mathrm{p}<0.05$ is considered statistically significant by ANOVA $\left(\mathrm{n}=9,{ }^{*} \mathrm{p}<0.05\right.$, $* * \mathrm{p}<0.01$ vs. control, $\# \mathrm{p}<0.05$, \#\#p<0.01 vs. 100 nM Aldo group).

Effects of Aldo on the Intracellular calcium concentrations $\left(\left[\mathrm{Ca}^{2+}\right]_{i}\right)$

As shown in Fig. 8. A and B, Aldo significantly decreased the level of $\left[\mathrm{Ca}^{2+}\right]_{\mathrm{i}}$ in a dosedependent manner as follows: control group: $21.62 \pm 3.31,0.1 \mathrm{nM}$ Aldo:29.92 $\pm 3.24(\mathrm{P}<0.05$, $\mathrm{n}=3), 1 \mathrm{nM}$ Aldo: $37.20 \pm 3.62(\mathrm{P}<0.01, \mathrm{n}=3), 10 \mathrm{nM}$ Aldo: $57.60 \pm 3.16(\mathrm{P}<0.01, \mathrm{n}=3)$, and $100 \mathrm{nM}$ Aldo: $74.80 \pm 2.85(\mathrm{P}<0.01, \mathrm{n}=3)$, suggesting that the classical $\mathrm{PKC}$ pathway might be activated. 
A
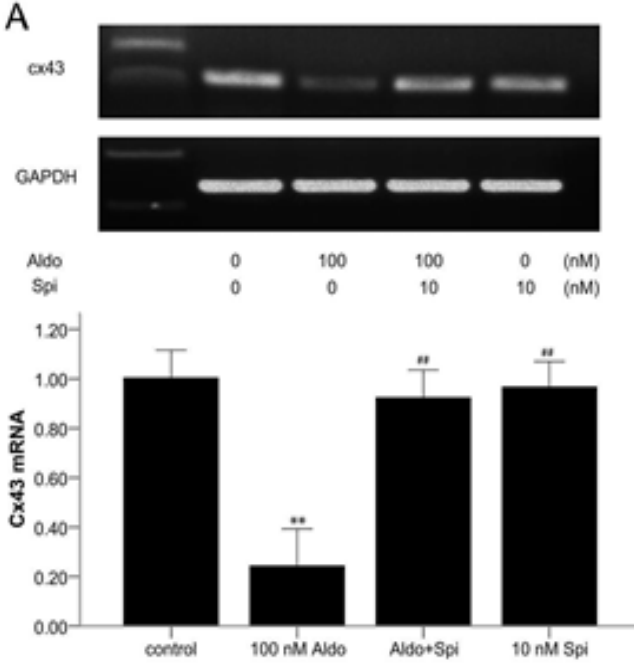

C

cx43

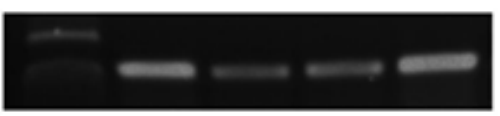

GAPDH

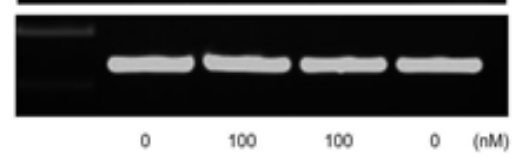

Nodo
LY
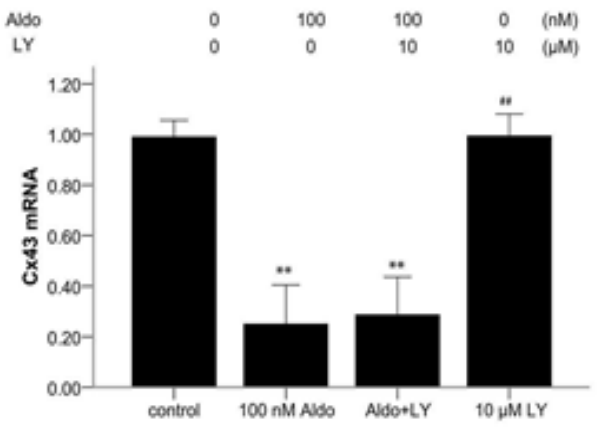

B

$0 \times 43$

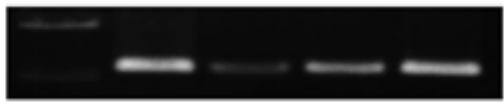

GAPOH
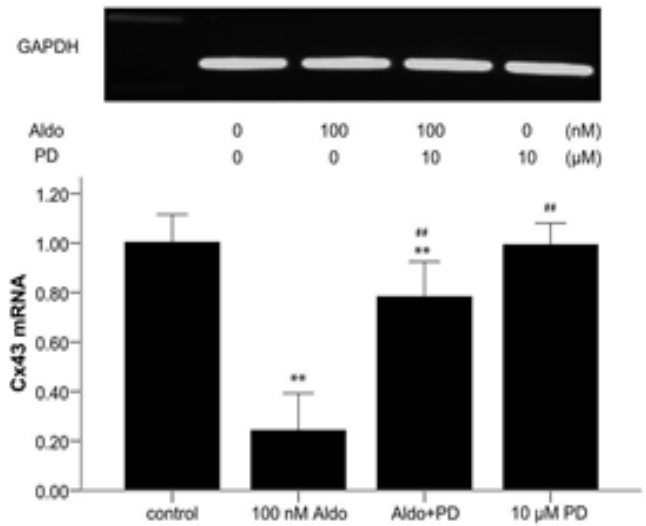

D $\mathrm{c} \times 43$

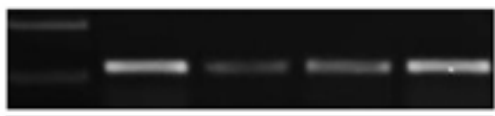

GAPOH

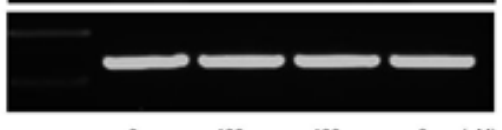

Aldo

GF

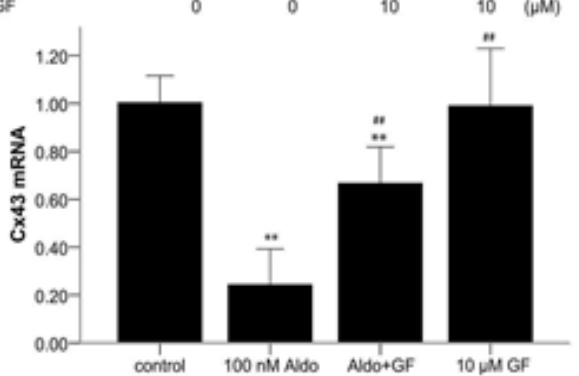

Fig. 6. Involvement of MR, ERK1/2, PI3K, and PKC kinase in Cx43 mRNA expression by RT-PCR. Spironolactone $(10 \mathrm{nM})$, PD98059 $(10 \mu \mathrm{M})$, LY294002 $(10 \mu \mathrm{M})$ or GF109203X (10 $\mu \mathrm{M})$ was administered concomitantly with $100 \mathrm{nM}$ Aldo for $24 \mathrm{~h}$ to cultured MCs. Total RNA was extracted from cultured MCs and analyzed by RT-PCR as described in the Materials and Methods for Cx43 and GAPDH. "Control" refers to cells growing in DMEM containing 10\% FCS without Aldo intervention. Values are given as the mean \pm S.D, and $\mathrm{p}<0.05$ is considered statistically significant by ANOVA $\left(n=3,{ }^{*} p<0.05,{ }^{* *} p<0.01\right.$ vs. control, $\# p<0.05, \# \# p<0.01$ vs. 100 nM Aldo group).

\section{Discussion}

Over the past several decades, various biological mechanisms have been demonstrated [8-10]; however, the mechanism by which Aldo regulates MC growth is far from clear. Recently, the role of connexins as 'players' in the field of growth regulation, not only in many types of cancer $[17,18]$ but also in normal cells $[19,20]$, has gained increasing attention. As the most abundant and extensively studied connexin, $\mathrm{Cx} 43$ has dual functions in controlling cell growth, dependent on or independent of the gap-junctional communication capacity $[21,22]$. In addition, it should be noted that $\mathrm{Cx} 43$ has a half-life in the range of $1-3 \mathrm{~h}$ in cultured cells or in tissues [23-25]. Therefore, it seems reasonable that stimulation by Aldo for $24 \mathrm{~h}$ would allow for a several-fold turnover in Cx43 protein. Additionally, this time 


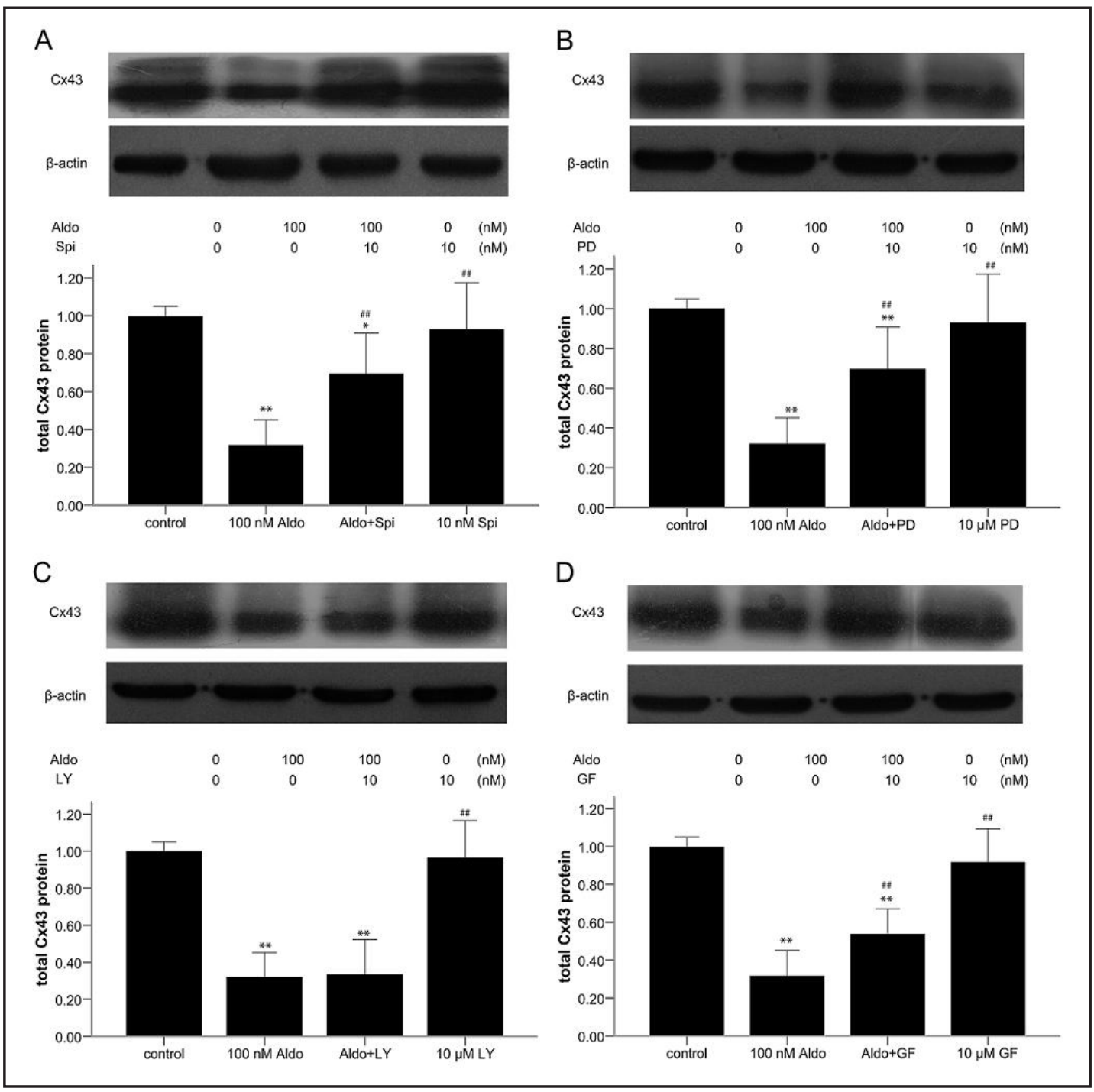

Fig. 7. Involvement of MR, ERK1/2, PI3K, and PKC kinase in total Cx43 protein expression by Western blot analysis. Spironolactone (10 nM), PD98059 $(10 \mu \mathrm{M})$, LY294002 $(10 \mu \mathrm{M})$ or GF109203X $(10 \mu \mathrm{M})$ was administered concomitantly with $100 \mathrm{nM}$ Aldo for $24 \mathrm{~h}$ to cultured MCs. Total cellular protein was extracted. Thirty micrograms of protein was loaded for Western blot analysis of total Cx43 and $\beta$-actin. "Control" refers to cells growing in DMEM containing 10\% FCS without Aldo intervention. Values are given as the mean \pm S.D, and $\mathrm{p}<0.05$ is considered statistically significant by ANOVA $\left(\mathrm{n}=3,{ }^{*} \mathrm{p}<0.05,{ }^{* *} \mathrm{p}<0.01\right.$ vs. control, $\# \mathrm{p}<0.05$, \#\#p<0.01 vs. 100 nM Aldo group).

schedule might simulate a long-term or 'chronic' response to Aldo, which can be expected in mesangial proliferative renal disease.

Our data showed that Aldo treatment for $24 \mathrm{~h}$ dose-dependently repressed $\mathrm{Cx} 43$ expression and promoted cell proliferation in MCs (Fig. 1.2), suggesting a potential role of $\mathrm{Cx} 43$ in the negative regulation of MC proliferation. As previously reported, the lack of Cx43 led to enhanced proliferation of fibroblast-like cells from Cx43-null mice [26]. Moreover, in primary cultures, silencing Cx43 enhanced the rate of astrocyte proliferation [27], which is characterized by the upregulation of cyclins D1 and D3 [28]. By contrast, restoration of Cx43 in glioma cells decreased the rate of proliferation [29, 30]. Nevertheless, Cheng et al. have reported that the up-regulation of $\mathrm{Cx} 43$ expression is necessary for basic fibroblast growth factor (bFGF) to maintain neural progenitor cells (NPCs) in a proliferative and self-renewal 
Fig. 8. A) Effects of Aldo on intracellular calcium concentration $\left(\left[\mathrm{Ca}^{2+}\right]_{\mathrm{i}}\right)$ using laser scanning confocal microscopy after loading by Fura-3/AM. Magnification, 10x. The rat MCs were treated with Aldo at a concentration of $0.1,1,10$ or $100 \mathrm{nM}$ for $24 \mathrm{~h}$. Then, $\left[\mathrm{Ca}^{2+}\right]_{\mathrm{i}}$ was examined as described in the Materials and Methods section. B). Quantitative analysis of the fluorescence gray value $\left(\left[\mathrm{Ca}^{2+}\right]_{\mathrm{i}}\right.$ concentrations in Aldo-induced MC proliferation). "Control" refers to cells growing in DMEM containing $10 \%$ FCS without Aldo intervention. Values are given as the mean \pm S.D, and $\mathrm{p}<0.05$ is considered statistically significant by ANOVA $(n=3$, ${ }^{*} \mathrm{p}<0.05,{ }^{* *} \mathrm{p}<0.01$ vs. control).

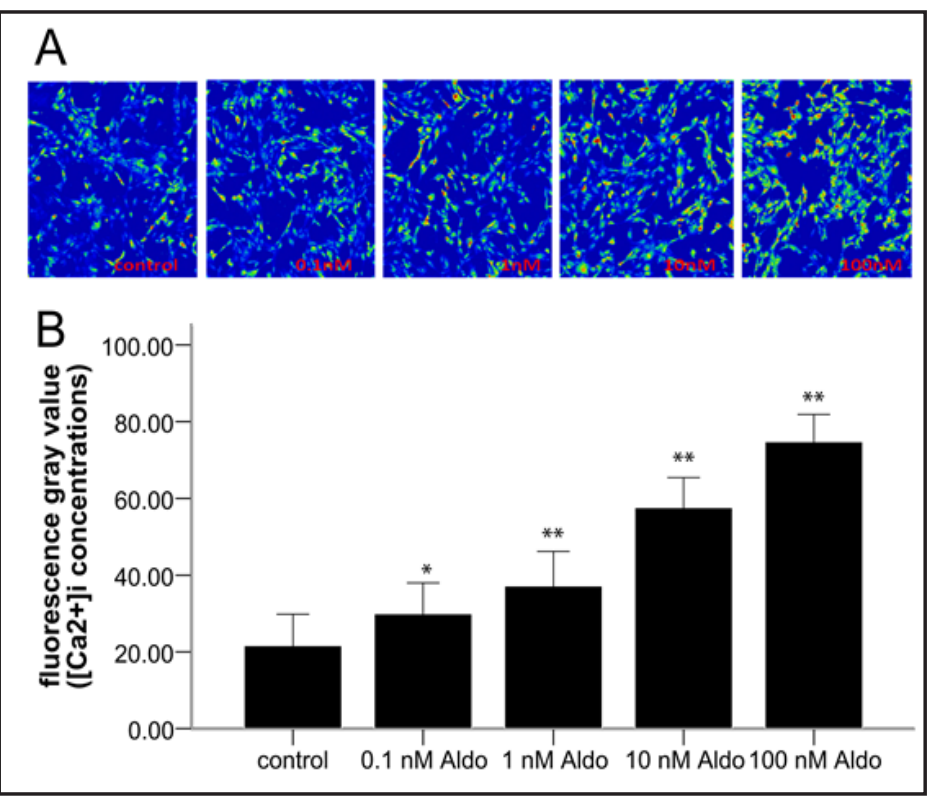

state [31]. In addition, the decreased proliferation in response to the reduction of the Cx43 expression levels has been observed in primary arterial smooth muscle cells (SMC) [32]. Unlike in our study, Yao et al. reported that the short-term (within $2 \mathrm{~h}$ ) or long-term (48 h) exposure of MCs to $30 \mathrm{ng} / \mathrm{ml}$ PDGF-BB did not alter the level of total $\mathrm{Cx} 43$ protein expression [33]. Taken together, this discrepancy between up- or down-regulation of Cx43 expression and cell proliferation may be attributed to cell-, tissue- or connexin-type specificity, different culture conditions, different time courses of stimulator addition, and different concentrationrelated responses as well as reflect the many facets of connexin function and regulation. Thus, there was insufficient evidence to conclude that Aldo-induced MC proliferation was mediated by down-regulating $\mathrm{Cx} 43$ expression. To verify this viewpoint, cell proliferation was re-analyzed by treatment with Aldo under the condition of elevated $\mathrm{Cx} 43$ expression. Then, $\mathrm{Cx} 43$ over-expression decreased cell proliferation (Fig. 4). Taken together, these results indicated that Aldo promoted MC proliferation by directly down-regulating Cx43 expression at the transcriptional and translational levels.

In addition to the expression of $\mathrm{Cx} 43$ contributing to MC proliferation, another point to address was whether Cx43 was also capable of inducing changes in the gap junction channel function, which was analyzed by SLDT [34]. In the present study, there was no difference in the length of dye between the four groups exposed to Aldo at different concentrations and the control group (Fig. 5). Therefore, our data might support the hypothesis that Cx43mediated MC proliferation may be independent of its well-accepted role in forming a gap junction channel; it could instead act via connexin-dependent mechanisms. In addition to the effects on gene and protein expression that have been confirmed above, connexindependent mechanisms was involved in $\mathrm{Cx} 43$ localization, its interactions with growth regulating partners (e.g., $\beta$-catenin, ZO-1 and CCN proteins), and its phosphorylation at specific sites [35]. Unfortunately, the present data do not allow for a firm conclusion about the precise molecular mechanism by which $\mathrm{Cx} 43$ affects cell proliferation, meriting further investigation.

In view of two confirmed pathways (MAPK and PI3K pathways) involved in Aldo-induced MC proliferation $[6,7]$, we sought to determine whether the similar signaling mechanisms contribute to Aldo-induced Cx43 reduction. Fortunately, we found that $\mathrm{Cx} 43$ reduction was significantly reversed for both the mRNA and protein levels by treatment with the MR antagonist spironolactone (Fig. 6.A and 7.A) and ERK1/2 inhibitor PD98059 (Fig. 6.B and 7.B). Nevertheless, the PI3K inhibitor LY294002 affected neither the mRNA nor protein level of Cx43 (Fig. 6.C and 7.C), but it blocked Aldo-induced cell proliferation (Fig. 1.B). Therefore, 
our results seemed to indicate the hypothesis that $\mathrm{Cx} 43$ expression in Aldo-induced MC proliferation might not be regulated, at least at the transcriptional and translational levels, via the PI3K pathway. Instead, it may possibly be mediated through activation of the PI3K pathway and then induction of other downstream molecules. Just as previously reported, in human MCs, Aldo activated PI3K, subsequently enhanced Akt, mTOR and p70S6 phosphorylation, and finally promoted cell proliferation [6]. In addition, in MCs, the effect of PDGF-BB on Cx43 expression is mediated by PI3K-dependent pathways, considering that the PI3K inhibitor LY294002 prevented the activation of ERK and phosphorylation of Cx43 [14].

$\mathrm{PKC}$ is another important pathway implicated in regulating a broad spectrum of cellular functions, including growth, proliferation, differentiation, and carcinogenesis. The PKC isoforms belong to three groups based on calcium dependency and activators. Classical PKCs (including the $\alpha, \beta 1, \beta 2$, and $\gamma$ isoforms) are calcium-dependent, novel PKCs (including the $\delta, \varepsilon, \eta$, and $\theta$ isoforms), and atypical PKCs (including the $\xi, \lambda$, and $\tau$ isoforms) are calcium independent. Several studies have shown that the PKC family, mainly classical PKCs, are implicated in Cx43 phosphorylation at multiple serines (S365, S368, S369, S372, and S373) $[36,37]$, expression [38] and GJIC regulation [39-41]. We found, for the first time, that inhibition of PKC pathways by GF109203X could also block MC proliferation (Fig. 1.B) and reverse down-regulation of $\mathrm{Cx} 43$ expression (Fig. 6.D and 7.D), which matched the effects of the inhibition of the MR, ERK1/2, and PI3K pathways. In addition, Aldo promoted MC proliferation, which was in parallel with increasing $\left[\mathrm{Ca}^{2+}\right]_{i}$ in a dose-dependent manner (Fig. 8. A and B). Combined with both aspects, it would ultimately be more plausible, not less, that the PKC pathway might be involved in Aldo-induced MC proliferation.

\section{Conclusions}

Taken together, our data support the hypothesis that $\mathrm{Cx} 43$ is an important regulator of Aldo-promoted MC proliferation. Furthermore, this is related to down-regulation of the transcriptional and translational levels and is not likely due to changes in the gap junction channel function. This process may be MR-mediated and dependent on the ERK1/2 and PKC pathways without being affected by the PI3K-dependent pathways. Furthermore, the involvement of the ERK1/2 and PKC pathways in Cx43 expression also acts as a good example of the close coordination of molecular events that is of great relevance in cell growth control. However, further investigation is needed to determine whether the in vitro results could be extended to conditions in vivo, how the signaling pathways were activated, and how $\mathrm{Cx} 43$ affects cell proliferation through additional mechanisms. Here, connexins provide us a new option for exploring the molecular mechanism of Aldo-induced MC proliferation, which may also serve as a potential therapeutic approach for mesangial proliferative renal disease.

\section{Acknowledgments}

This work was sponsored by the Scientific Research Program from Nanjing Medical University (No. 2011NJMU251) and by the Health department of Nanjing, China (No. QYK11226).

\section{Disclosure Statement}

The authors have declared no conflict of interest

\section{References}

1 Fujita T: Aldosterone and CKD in metabolic syndrome. Curr Hypertens Rep 2008;10:421-423.

2 Blasi ER, Rocha R, Rudolph AE, Blomme EA, Polly ML, McMahon EG: Aldosterone/salt induces renal inflammation and fibrosis in hypertensive rats. Kidney Int 2003;63:1791-1800.

\section{KARGER}




\section{Cellular Physiology Cell Physiol Biochem 2015;36:1210-1222 \begin{tabular}{l|l|l}
\hline DOI: 10.1159/000430291 & C 2015 S. Karger AG, Basel
\end{tabular} www.karger.com/cpb

3 Claassen K, Willmann S, Eissing T, Preusser T, Block M: A detailed physiologically based model to simulate the pharmacokinetics and hormonal pharmacodynamics of enalapril on the circulating endocrine ReninAngiotensin-aldosterone system. Front Physiol 2013;4:4.

4 Tylicki L, Larczynski W, Rutkowski B: Renal protective effects of the renin-angiotensin-aldosterone system blockade: from evidence-based approach to perspectives 2005;28:230-242.

5 Baltatzi M, Savopoulos C, Hatzitolios A: Role of angiotensin converting enzyme inhibitors and angiotensin receptor blockers in hypertension of chronic kidney disease and renoprotection. Study results. Hippokratia 2011;15:27-32.

6 Huang S, Zhang A, Ding G, Chen R: Aldosterone-induced mesangial cell proliferation is mediated by EGF receptor transactivation. Am J Physiol Renal Physiol 2009;296:F1323-1333.

7 Nishiyama A, Yao L, Fan Y, Kyaw M, Kataoka N, Hashimoto K: Involvement of aldosterone and mineralocorticoid receptors in rat mesangial cell proliferation and deformability. Hypertension 2005;45:710-716.

8 Yuan Y, Zhang A, Huang S, Ding G, Chen R: A PPARgamma agonist inhibits aldosterone-induced mesangial cell proliferation by blocking ROS-dependent EGFR intracellular signaling. Am J Physiol Renal Physiol 2011;300:F393-402.

9 Terada Y, Kobayashi T, Kuwana H, Tanaka H, Inoshita S, Kuwahara M: Aldosterone stimulates proliferation of mesangial cells by activating mitogen-activated protein kinase $1 / 2$, cyclin D1, and cyclin A. J Am Soc Nephrol 2005;16:2296-2305.

10 Otani H, Otsuka F, Inagaki K, Takeda M, Miyoshi T, Suzuki J: Antagonistic effects of bone morphogenetic protein-4 and - 7 on renal mesangial cell proliferation induced by aldosterone through MAPK activation. Am J Physiol Renal Physiol 2007;292:F1513-1525.

11 Wagner C: Function of connexins in the renal circulation. Kidney Int 2008;73:547-555.

12 Hanner F, Sorensen CM, Holstein-Rathlou NH, Peti-Peterdi J: Connexins and the kidney. Am J Physiol Regul Integr Comp Physiol 2010;298:R1143-1155.

13 Jose PA, Chen S, Armando I: Connections in chronic kidney disease: connexin 43 and connexin 37 interaction. Am J Physiol Renal Physiol 2011;301:F21-23.

14 Yao J, Morioka T, Oite T: PDGF regulates gap junction communication and connexin43 phosphorylation by PI3-kinase in mesangial cells. Kidney Int 2000;57:1915-1926.

15 Chen M, Liu Y, Yi D, Wei L, Li Y, Zhang L. Tanshinone IIA promotes pulmonary artery smooth muscle cell apoptosis in vitro by inhibiting the JAK2/STAT3 signaling pathway. Cell Physiol Biochem 2014;33:11301138.

16 Li H, Tang M, Liang H, Li Y, Wang J, Song Y, Zheng Y, Xi J, Zhang J, Hescheler J, Zhu M. Coculture of embryonic ventricular myocytes and mouse embryonic stem cell enhance intercellular signaling by upregulation of connexin43. Cell Physiol Biochem 2013;32:53-63.

17 Chandrasekhar A, Kalmykov EA, Polusani SR, Mathis SA, Zucker SN, Nicholson BJ: Intercellular redistribution of cAMP underlies selective suppression of cancer cell growth by connexin26. PLoS One 2013;8:e82335.

18 El-Saghir JA, El-Habre ET, El-Sabban ME, Talhouk RS: Connexins: a junctional crossroad to breast cancer. Int J Dev Biol 2011;55:773-780.

19 Doble BW, Dang X, Ping P, Fandrich RR, Nickel BE, Jin Y: Phosphorylation of serine 262 in the gap junction protein connexin-43 regulates DNA synthesis in cell-cell contact forming cardiomyocytes. J Cell Sci 2004;117:507-514.

20 Yang M, Wang B, Li M, Jiang B. Connexin 43 is involved in aldosterone-induced podocyte injury. Cell Physiol Biochem 2014;34:1652-1662.

21 Moorby C, Patel M: Dual functions for connexins: Cx43 regulates growth independently of gap junction formation. Exp Cell Res 2001;271:238-248.

22 Hills CE, Kerr MI, Wall MJ, Squires PE. Visfatin reduces gap junction mediated cell-to-cell communication in proximal tubule-derived epithelial cells. Cell Physiol Biochem 2013;32:1200-1212.

23 Beardslee MA, Laing JG, Beyer EC, Saffitz JE: Rapid turnover of connexin43 in the adult rat heart. Circ Res 1998;83:629-635.

24 Lampe PD: Analyzing phorbol ester effects on gap junctional communication: a dramatic inhibition of assembly. J Cell Biol 1994;127:1895-1905. 


\section{Cellular Physiology Cell Physiol Biochem 2015;36:1210-1222 \begin{tabular}{l|l} 
DOI: 10.1159/000430291 & O 2015 S. Karger AG, Basel
\end{tabular} www.karger.com/cpb \\ Zhang et al.: Cx43 Regulates Mesangial Cell Proliferation}

25 Musil LS, Cunningham BA, Edelman GM, Goodenough DA: Differential phosphorylation of the gap junction protein connexin43 in junctional communication-competent and -deficient cell lines. J Cell Biol 1990;111:2077-2088.

26 Martyn KD, Kurata WE, Warn-Cramer BJ, Burt JM, TenBroek E, Lau AF: Immortalized connexin43 knockout cell lines display a subset of biological properties associated with the transformed phenotype. Cell Growth Differ 1997;8:1015-1027.

27 Herrero-Gonzalez S, Valle-Casuso JC, Sanchez-Alvarez R, Giaume C, Medina JM, Tabernero A: Connexin43 is involved in the effect of endothelin-1 on astrocyte proliferation and glucose uptake. Glia 2009;57:222-233.

28 Tabernero A, Sanchez-Alvarez R, Medina JM: Increased levels of cyclins D1 and D3 after inhibition of gap junctional communication in astrocytes. J Neurochem 2006;96:973-982.

29 Herrero-Gonzalez S, Gangoso E, Giaume C, Naus CC, Medina JM, Tabernero A: Connexin43 inhibits the oncogenic activity of c-Src in C6 glioma cells. Oncogene 2010;29:5712-5723.

30 Naus CC, Laird DW: Implications and challenges of connexin connections to cancer. Nat Rev Cancer 2010;10:435-441.

31 Cheng A, Tang H, Cai J, Zhu M, Zhang X, Rao M: Gap junctional communication is required to maintain mouse cortical neural progenitor cells in a proliferative state. Dev Biol 2004; 272: 203-216.

32 Matsushita T, Rama A, Charolidi N, Dupont E, Severs NJ: Relationship of connexin43 expression to phenotypic modulation in cultured human aortic smooth muscle cells. Eur J Cell Biol 2007;86:617-628.

33 Yao J, Kitamura M, Zhu Y, Meng Y, Kasai A, Hiramatsu N: Synergistic effects of PDGF-BB and cAMP-elevating agents on expression of connexin43 in mesangial cells. Am J Physiol Renal Physiol 2006;290:F1083-1093.

34 El-Fouly MH, Trosko JE, Chang CC: Scrape-loading and dye transfer. A rapid and simple technique to study gap junctional intercellular communication. Exp Cell Res 1987; 168: 422-430.

35 Kardami E, Dang X, Iacobas DA, Nickel BE, Jeyaraman M, Srisakuldee W: The role of connexins in controlling cell growth and gene expression. Prog Biophys Mol Biol 2007;94:245-264.

36 Doble BW, Ping P, Fandrich RR, Cattini PA, Kardami E: Protein kinase C-epsilon mediates phorbol esterinduced phosphorylation of connexin-43. Cell Commun Adhes 2001;8:253-256.

37 Joshi CN, Martin DN, Shaver P, Madamanchi C, Muller-Borer BJ, Tulis DA: Control of vascular smooth muscle cell growth by connexin 43. Front Physiol 2012;3:220.

38 Yu L, Zhao Y, Xu S, Ding F, Jin C, Fu G: Advanced Glycation End Product (AGE)-AGE Receptor (RAGE) System Upregulated Connexin43 Expression in Rat Cardiomyocytes via PKC and Erk MAPK Pathways. Int J Mol Sci 2013;14:2242-2257.

39 Lampe PD, Lau AF: The effects of connexin phosphorylation on gap junctional communication. Int J Biochem Cell Biol 2004;36:1171-1186.

40 Nihei OK, Fonseca PC, Rubim NM, Bonavita AG, Lyra JS, Neves-dos-Santos S: Modulatory effects of cAMP and PKC activation on gap junctional intercellular communication among thymic epithelial cells. BMC Cell Biol 2010;11:3.

41 Piccoli C, D'Aprile A, Scrima R, Ambrosi L, Zefferino R, Capitanio N: Subcytotoxic mercury chloride inhibits gap junction intercellular communication by a redox- and phosphorylation-mediated mechanism. Free Radic Biol Med 2012;52 916-927. 